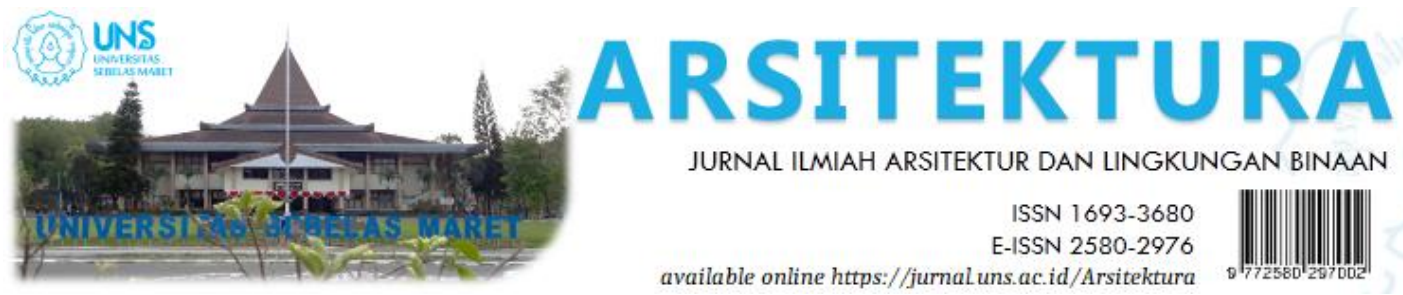

Volume 18 Issue 1 April 2020, pages: 151-165

\title{
Tipologi Penyediaan Infrastruktur Perumahan di Kawasan Peri- urban Utara-Selatan Metropolitan Bandung Raya
}

\section{The Typology of Housing Infrastructure Provision in The Northern - Southern Peri-Urban of Bandung Metropolitan Area}

\author{
Anita Vitriana \\ Badan Penelitian dan Pengembangan Daerah (BP2D) Provinsi Jawa Barat \\ Email: avitriana@yahoo.com
}

DOI: https://doi.org/10.20961/arst.v18i1.35021

Received: October 17, 2019 Revised: January 13,2020 Accepted: January 24,2020 Available online:April 30, 2020

\begin{abstract}
Bandung Municipality has been experiencing in expanding its region to become greater area as Bandung Metropolitan Area (BMA). With a very wide scope of territory, cross borderadministrative, and the number of developers involved, it has led to different character of infrastructure provision, particularly between the residential in the northern and southern part of the peri-urban BMA. This study aims to identify the issues of infrastructure provision in both areas through a micro-empirical study. The character identification is in terms of availability and accessibility according to the SNI 03-1733-2004 on Procedures for Housing Environmental Planning in Urban. The typology of peri-urban areas is represented by two villages in the northern and southern of BMA. Data source is obtained by the primary and secondary method. The analysis uses the simple qualitative method and the content analysis approach. The results show that the northern housing typology is superior in terms of providing clean water infrastructure and the standard electricity capacity, but it has lack provision of commercial and trade facilities. While the southern housing typology is on the contrary. It excels in the provision of commercial and trade facilities, but it has inadequate provision of clean water and the electricity capacity.
\end{abstract}

Keywords: residential, infrastructure provision, peri-urban BMA, northern-southern typology

\section{PENDAHULUAN}

Pertambahan penduduk serta pertambahan kebutuhan hunian adalah dampak yang akan selalu mengikuti perkembangan kota (UN Habitat, 2015). Namun demikian sebagai komponen alam yang sifatnya terbatas, lahan perkotaan pada titik tertentu tidak akan sanggup lagi menampung beban kebutuhan perumahan. Hal ini telah menimbulkan permintaan yang tinggi terhadap perumahan dan prasarana pendukungnya (Fahmi, Hudalah, Rahayu, \& Woltjer, 2014).
Akibatnya, pembangunan perumahan di kotakota besar sering kali melebar ke wilayah pinggiran/perbatasan kota (Winarso, Hudalah, \& Firman, 2015).

Suburnya pertumbuhan permukiman perkotaan di wilayah peri-urban merupakan kompleksitas respon atas permintaan pasar perumahan masyarakat kota (Hudalah, Winarso, \& Woltjer, 2014). Hal ini tidak terlepas dari paradigma penggunaan wilayah peri-urban yang dianggap paling menyenangkan untuk digunakan sebagai tempat tinggal karena 
dianggap bebas dari kemacetan, polusi udara dan kepadatan sebagaimana yang terjadi pada wilayah kota (Rustiati, 2005). Kesempatan ini direspon oleh pengembang swasta yang berlomba untuk menyediakan perumahan periurban dengan menciptakan lingkungan hunian yang memiliki infrastruktur dan lingkungan yang jauh lebih baik dari pada permukiman dalam kota (Firman, 2009).

Bandung Raya sebagai kota metropolitan ketiga terbesar di Indonesia, telah mengalami perkembangan aktifitas perkotaan yang melibatkan wilayah sekitarnya hingga membentuk kawasan perkotaan yang lebih luas dengan nama Kawasan Metropolitan Bandung Raya. Berdasarkan Peraturan Daerah Provinsi Jawa Barat no. 12 Tahun 2014 tentang Pengelolaan Pembangunan dan Pengembangan Metropolitan dan Pusat Pertumbuhan di Jawa Barat, Metropolitan Bandung Raya terdiri dari seluruh Wilayah Kota Bandung dan Kota Cimahi, dan sebagian wilayah Kabupaten Bandung, Kabupaten Bandung Barat (KBB). Pesatnya pertumbuhan peri-urban Metropolitan Bandung Raya ditandai dengan tingginya angka pertumbuhan penduduk Kabupaten/Kota yang berada disekeliling Kota Bandung. Sebagaimana dijelaskan pada Laporan Kajian Teknis Penyusunan Masterplan Penyediaan Perumahan Rakyat di Metropolitan Bandung Raya Tahun 2015 (Direktorat Perencanaan Penyediaan Perumahan, 2015), pertumbuhan penduduk rata-rata di Metropolitan Bandung Raya adalah sebesar $1.56 \%$ sementara rata-rata pertumbuhan penduduk Kota Bandung hanya sebesar $1.21 \%$ atau paling rendah jika dibandingkan dengan wilayah disekelilingnya.

Tingginya pertumbuhan penduduk di Kawasan pinggiran peri-urban Metropolitan Bandung Raya diikuti dengan peningkatan pemanfaatan wilayah pinggiran Kota Bandung untuk kebutuhan aktivitas perkotaan. Tren penyediaan perumahan yang mendukung pengembangan aktivitas urban Kota Bandung terus melebar hingga mencakup ke beberapa wilayah di kabupaten/kota di sekitarnya (Direktorat Perencanaan Penyediaan Perumahan, 2015). Tingginya peran sektor swasta dalam pembangunan kawasan periurban sering menjadi polemik diantara banyak pihak. Dalam hal ini, setiap pembangunan kawasan tentunya akan diikuti dengan kebutuhan terhadap infrastruktur permukiman (Mittal \& Kashyap, 2015). Keterlibatan sektor swasta dalam pengembangan kawasan periurban dapat dilihat dari dua sisi yang berbeda. Dari sudut pandang positif, keterlibatan mereka dapat dikatakan sebagai agen yang membantu pemerintah dalam percepatan penyediaan perumahan dan pembangunan infrastruktur permukiman di kawasan periurban sebagaimana yang disampaikan oleh Siahaan, Nasution, dan Purwoko (2014) yang dalam penelitiannya tentang pengembangan perumahan formal di Kecamatan Siantar Marimbun Provinsi Sumatera Utara membuktikan bahwa keterlibatan pengembang perumahan memiliki korelasi positif terhadap pengembangan infrastruktur kawasan.

Di sisi lain, tingginya peran sektor swasta dalam mengembangkan perumahan dan pembangunan infrastruktur permukiman periurban, seringkali dianggap sebagai penyebab munculnya fenomena ketidakteraturan dan fragmentasi spasial yang banyak timbul di kawasan peri-urban negara-negara berkembang di Asia Tenggara (Divigalpitiya \& Handayani, 2010). Fragmentasi tersebut biasanya terjadi antara satu kawasan perumahan formal dengan kawasan perumahan formal lainnya, ataupun antara satu kawasan perumahan dengan permukiman eksisting di sekitarnya (Hudalah, Winarso, \& Woltjer, 2007). Dalam hal ini, perumahan formal biasanya dibangun oleh pengembang swasta yang mampu membangun jaringan infrastruktur sendiri, tanpa perlu bergantung pada kondisi infrastruktur eksisting (Maryati, Nisaa, \& Humaira, 2015).

Pada kondisi pengembangan perumahan di kawasan peri-urban yang didominasi sektor swasta, tingginya pembangunan perumahan sering tidak selaras dengan pemerataan ketersediaan infrastruktur kawasan (Okoro, Musonda, \& Agumba, 2016). Dalam hal ini, sektor swasta berfokus pada penyediaan fasilitas kawasannya dan kurang memperhatikan dampak eksternalitas pada lingkungan sekitarnya (Guo, Xiao, \& Yuan, 2016). Eksternalitas yang timbul akibat ketidakteraturan dan ketidakmerataan ketersedian infrastruktur dalam skala makro sering berdampak pada munculnya 
permasalahan lingkungan dan sosial (Zhao, 2013; Zhang, Zhou, \& Mao, 2019).

Pada kawasan perdesaan yang termasuk dalam cakupan delineasi pengembangan Metropolitan Bandung Raya, saat ini telah banyak berdiri kompleks perumahan yang dibangun oleh pengembang. Isu ketidakmerataan ketersediaan infrastruktur permukiman di kawasan Metropolitan Bandung Raya diataranya timbul sebagai akibat dari luasnya cakupan wilayah yang meliputi 5 kota/kabupaten yang berbeda, dengan karakteristik fisik, geografis, sosial-ekonomi, administrasi pemerintahan lokal yang berbeda yang sangat berpengaruh pada karakteritik penyediaan perumahan dan infrastruktur permukimannya. Salah satu hal yang paling menonjol ditunjukkan oleh perbedaan karakter permukiman utara-selatan dimana perumahan yang berada pada wilayah utara Bandung cenderung memiliki satuan unit lahan yang luas karena persyaratan Koefisien Dasar Bangunan (KDB) yang cukup ketat. Terlepas dari perbedaan geografis tersebut, ketersediaan jaringan infrastruktur yang layak dan memadai merupakan syarat mutlak dalam penyelenggaraan perumahan.

Dengan banyaknya isu makro tentang kesenjangan infrastruktur permukiman di kawasan pinggiran kota, khususnya di kawasaan peri-urban Metropolitan Bandung Raya, perlu diketahui bagaimana praktek penyediaan infrastruktur secara mikro berikut aspek-aspek krusial yang perlu ditangani segera oleh pemerintah. Kajian mikro ini pun dapat mengurai aspek ketidakteraturan infrastruktur makro yang sekarang terjadi. Hasil identifikasi dan evaluasi sistem penyediaan dan pemanfaatan infrastruktur permukiman peri-urban secara mikro diharapkan dapat menjadi bahan evaluasi dan masukan dalam pembenahan pengaturan sistem penyediaan infrastruktur kawasan perkotaan yang sedang berkembang, khususnya di kawasan peri-urban Metropolitan Bandung Raya (Vitriana 2017).

\section{METODE}

Pada penelitan ini, identifikasi karakter infrastruktur dilakukan melalui studi empirik dengan metoda studi kasus. Penelitian ini dilakukan pada dua lokasi studi kasus permukiman yang terletak di wilayah inner fringe (Tian, Ge, \& Li, 2016) Metropolitan Bandung Raya, yang masing-masingnya mewakili kawasan peri-urban Kabupaten Bandung dan KBB. Kemudian, pada kedua kawasan tersebut dipilih tiga kompleks perumahan yang masing-masingnya dianggap mewakili ketiga tipologi pengembang perumahan.

Penelitian ini menggunakan tiga metode pendekatan. Pendekatan pertama adalah metode penentuan objek studi kasus, pendekatan kedua adalah metode pengumpulan data dan pendekatan ketiga adalah metode analisis. Kategorisasi pengembangan perumahan pada penelitian ini merujuk pada Tipologi Pengembang yang diadaptasi dari studi Winarso (2000) tentang pengklasifikasikan pengembang perumahan formal di Wilayah Jabotabek. Sementara itu, identiikasi ketersediaan infrastruktur perumahan dan permukiman mengacu pada SNI 03-1733-2004 tentang Tata Cara Perencanaan Lingkungan Perumahan di Perkotaan (Badan Standardisasi Nasional, 2004). Secara umum, alur pelaksanaan penelitian dapat dilihat pada Gambar 1.

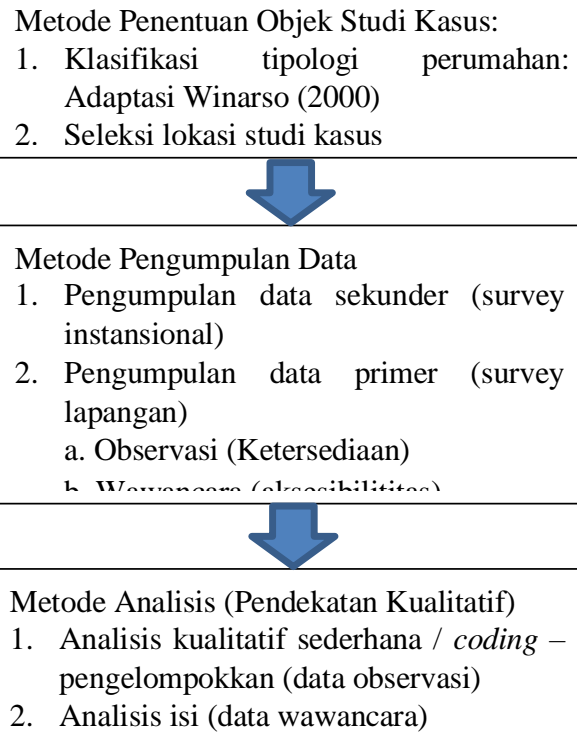

Metode Penentuan Objek Studi Kasus:

1. Klasifikasi tipologi perumahan: Adaptasi Winarso (2000)

2. Seleksi lokasi studi kasus

Metode Pengumpulan Data

1. Pengumpulan data sekunder (survey instansional)

2. Pengumpulan data primer (survey lapangan)

a. Observasi (Ketersediaan)

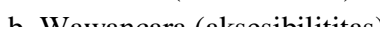

Metode Analisis (Pendekatan Kualitatif)

1. Analisis kualitatif sederhana / coding pengelompokkan (data observasi)

2. Analisis isi (data wawancara)

Gambar 1. Metodologi Penelitian 


\subsection{Metode Penentuan Objek Studi Kasus}

Tulisan ini menggunakan metode studi kasus untuk memperoleh informasi yang terperinci dan mendalam dari suatu fenomena. Merujuk kepada fenomena pengembangan perumahan yang terjadi di sebagaian besar wilayah periurban Kota Bandung, penelitian ini mengacu pada terminologi pengembang tipe footholders dengan berfokus pada aspek luas area perumahan yang dikembangkan. Dengan demikian, pembagian tipologi pengembangan perumahan terdiri atas tipologi kecil dengan luas perumahan kurang dari $5 \mathrm{Ha}$, tipologi menengah dengan luas perumahan antara 5-15 $\mathrm{Ha}$ dan tipologi besar untuk perumahan dengan luas > 15 Ha. Sampel lokasi pada penelitian ini adalah Desa Ciwaruga (KBB) sebagai representasi kawasan peri-urban utara dan Desa Cipagalo (Kabupaten Bandung) sebagai representasi objek kawasan peri-urban selatan. Adapun penentuan lokasi studi kasus tersebut dipilih berdasarkan pertimbangan:

1) pada keduanya terdapat ketiga tipologi pengembang perumahan formal peri-urban,

2) memiliki karakteristik perpaduan penggunaan lahan urban-rural yang menjadi salah satu ciri fisik dari kawasan peri-urban,

3) merupakan desa yang terletak pada wilayah administratif yang berbeda yang berbatasan langsung dengan Kota Bandung

4) secara geografis terletak pada wilayah yang kontras satu sama lain (batas utara - batas selatan Kota Bandung).

Dari masing-masing desa tersebut lalu dilakukan penentuan 3 kompleks perumahan yang mewakili ketiga tipologi perumahan formal. Adapun representasi lokasi studi terpilih pada Desa Ciwaruga meliputi (a) Perumahan Griya Amanda 3 (Tipologi Pengembangan Perumahan Skala Kecil), (b) Perumahan Gerlong Permai (Tipologi Pengembangan Perumahan Skala Menengah), dan (c) Perumahan Parahyangan Rumah Villa (Tipologi Pengembangan Perumahan Skala Besar), sementara perwakilan lokasi studi pada Desa Cipagalo meliputi (d) Perumahan Surya Asri Residence (Tipologi Pengembangan Perumahan Skala Kecil), (e) Perumahan Pesona Ciganitri (Tipologi Pengembangan Perumahan Skala Menengah), dan (f)
Perumahan Cherry Field (Tipologi Pengembangan Perumahan Skala Besar).

\subsection{Metode Pengumpulan Data}

Penelitian ini menggunakan teknik pengumpulan data primer dan sekunder. Pengumpulan data primer dilakukan melalui teknik observasi dan wawancara. Teknik observasi digunakan untuk memperoleh identifikasi karakteristik kuantitas infrastruktur perumahan, sementara teknik wawancara digunakan untuk memperoleh data kualitatif berupa informasi aksesibilitas penggunaan infrastruktur perumahan oleh masyarakat sekitar yang ada diluar lingkungan perumahan. Wawancara dilakukan pada 12 orang narasumber yang tersebar pada 6 lokus penelitian. Dua orang narasumber di setiap lokus penelitian tersebut terdiri dari satu orang narasumber pengelola perumahan (estate management/security) serta 1 orang narasumber perwakilan warga setempat (RT/tokoh masyarakat) yang tinggal di lingkungan luar masing-masing lokus perumahan yang diteliti. Pengumpulan informasi dari pihak internal dan eksternal perumahan dilakukan sebagai salah satu metode triangulasi data. Pengumpulan data sekunder dilakukan pada dinas yang membidangi masalah perumahan di Kab. Bandung dan KBB.

Sebagai sumber acuan kelengkapan persyaratan dan komponen infrastruktur yang dibutuhkan pada lingkungan perumahan, peneliti melakukan kajian terhadap beberapa sumber peraturan formal nasional, diantaranya UU No. 1 Tahun 2011 tentang Perumahan dan Kawasan Permukiman, PP No. 14 Tahun 2016 tentang Penyelenggaraan Perumahan dan Kawasan Permukiman, Permendagri No. 9 Tahun 2009 tentang Pedoman penyerahan Prasarana, Sarana dan Utilitas Perumahan dan Permukiman di Daerah, Permenpera No. 22/Permen/M/2008 tentang SPM Bidang Perumahan Rakyat Daerah Provinsi dan Daerah Kabupaten / Kota, Permenpera 34/Permen/M/2006 tentang Pedoman Umum Penyelenggaraan Keterpaduan PSU Kawasan Perumahan dan SNI 03-1733-2004 tentang Tata Cara Perencanaan Lingkungan Perumahan di Perkotaan. Penelitian ini 
menggunakan skema pengecekan ketersediaan infrastruktur perumahan dengan mengacu pada SNI 03-1733-2004 yang secara rinci menjelaskan standar-standar dan persyaratan lengkap infrastrukur yang harus dipenuhi dalam suatu lingkungan perumahan.

Pengumpulan data aksesibilitas mengacu pada aspek kemudahan dan kenyamanan untuk menjangkau dan menggunakan infrastruktur perumahan. Pada kajian ini, aksesibilitas infrastruktur akan ditinjau bukan dari sisi internal penghuni perumahan, namun dari persepsi masyarakat yang berada diluar lingkungan perumahan formal tersebut. Dalam hal ini, meskipun pengembang melakukan pembangunan infrastruktur perumahan sebagai kelengkapan fasilitas bagi penghuni, namun pada dasarnya infrastruktur adalah barang publik yang memiliki fungsi pelayanan luas (Sheng, 2014). Sebagaimana yang dijelaskan oleh Power \& Mee (2019) bahwa memahami infrastruktur dapat dilakukan sebagai sistem sosioteknik, dimana analisis infrastruktur dapat dilakukan dengan memperhatikan bagaimana infrastruktur memola kehidupan sosial dan mengidentifikasi nilai-nilai yang secara selektif dikodekan ke dalam infrastruktur. Untuk itu, pengertian aksesibilitas infrastruktur perumahan yang berkontribusi positif adalah yang memberi kemudahan akses penggunaan bagi lingkungan / masyarakat sekitar yang dicerminkan dengan ketiadaan hambatan fisik serta perletakan spasial yang strategis.

\subsection{Metode Analisis}

Penelitian ini menggunakan pendekatan analisis kualitatif campuran, yang meliputi metode analisis kualitatif sederhana dalam hal pengeolahan data hasil observasi lapangan serta metode analisis isi untuk mengolah data hasil wawancara dengan informan lapangan. Analisis kualitatif sederhana dilakukan dengan metoda coding-pengelompokkan-kesimpulan, sementara analisis isi dilakukan dalam beberapa tahapan, yang meliputi:

1) Mengorganisasi dan menyiapkan data

2) Membaca keseluruhan data yang terkonversi ke dalam bentuk teks untuk dapat memahami makna dan informasi

3) Mengkonversi teks ke dalam bentuk pengkodean
4) Melakukan matriks coding untuk mengetahui segmen teks yang beririsan dari berbagai kode
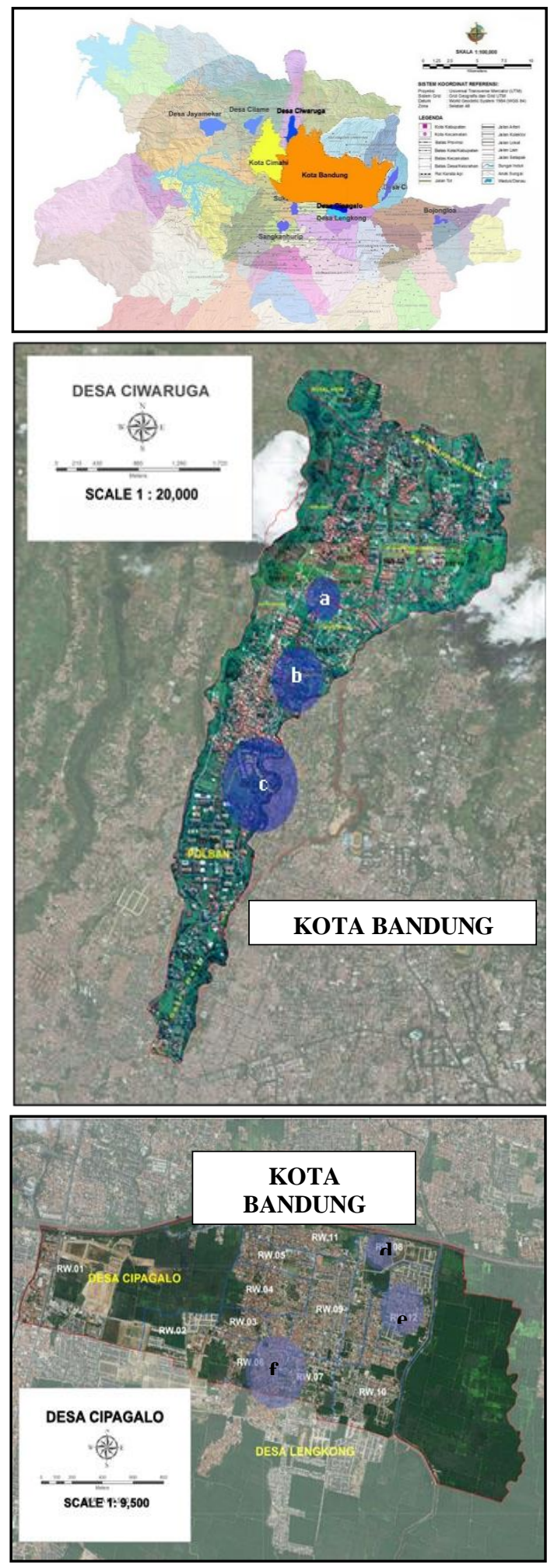

Gambar 2. Lokus Penelitian 
5) Melakukan pengelompokkan segmensegmen yang sama untuk memperoleh tema besar kelompok berdasarkan aspek ketersediaan dan aksesibilitas infrastruktur perumahan peri-urban Metropolitan Bandung Raya tipologi utara versus selatan.

\section{HASIL DAN PEMBAHASAN}

Pada tahap ini, penulis melakukan pengolahan data melalui teknik klasifikasi dan pengelompokkan data infrastruktur perumahan berdasarkan kategori utara dan selatan pada lokasi studi kasus yang telah ditentukan. Pada masing-masing kategori, telah terhimpun data tiga perumahan yang mewakili tipologi kecil, menengah dan besar. Adapun peta sebaran lokus penelitian dapat dilihat pada Gambar 2. Analisis data infrastruktur perumahan dilakukan berdasarkan aspek ketersediaan (kuantitas) dan aksesibilitas yang selanjutnya dipetakan dalam suatu model analisis identifikasi karakteristik infrastruktur perumahan dan permukiman di suatu kawasan.

\subsection{Analisis Aspek Ketersediaan}

Analisis aspek ketersediaan infrastruktur perumahan dilakukan pada ketiga sampel kompleks perumahan pada dua desa yang mewakili masing-masing tipologi luasan pengembang perumahan di kawasan periurban Metropolitan Bandung Raya utara dan selatan. Komponen pengujian identifikasi ketersediaan dan aksesiblitas infrastruktur perumahan dan permukiman pada penelitian ini meliputi kelengkapan sarana, prasarana dan utilitas (PSU) yang terdiri atas 7 komponen jaringan infrastruktur dasar dan 6 komponen sarana perumahan (Vitriana 2018). Penelitan aspek ketersediaan dikelompokkan atas kategori A (Tidak tersedia, namun belum wajib ada), B (Tidak tersedia, seharusnya ada), C (Tersedia, namun tidak memenuhi standar) dan D (Tersedia, memenuhi standar). Adapun pemetaan karakterstik ketersediaan infrastruktur perumahan pada keenam komplkes perumahan tersebut dapat dilihat pada Lampiran 1.

Berdasarkan hasil pemetaan identifikasi kondisi ketersediaan infrastrktur perumahan selanjutnya dibuat suatu pemodelan analisis ketersediaan infrastruktur perumahan. Pada model analisis ketersediaan infrastruktur perumahan, dilakukan pengelompokkan kategori dengan tema yang lebih luas, yang meliputi 1) kelompok infrastruktur yang tersedia dan 2) kelompok infrastruktur yang tidak tersedia. Pada kelompok infrastruktur tersedia, dibagi lagi menjadi sub kelompok tersedia dan memenuhi standar, sub kelompok tersedia tetapi tidak memenuhi standar dan kelompok tersedia antara memenuhi standar dan tidak. Pada kelompok tidak tersedia, dibagi dalam sub kelompok tidak tersedia padahal seharusnya ada, sub kelompok tidak tersedia dan belum wajib, serta sub kelompok tidak tersedia antara seharusnya ada dan belum wajib ada. Sub kelompok terakhir adalah kelompok antara tersedia dan tidak. Model analisa pemetaan karakteristik ketersediaan infrastruktrur perumahan dapat dilihat pada Lampiran 2. Secara umum, model tersebut menggambarkan pemetaan aspek-aspek ketersediaan (kuantitas) infrastruktur yang semakin baik ke arah kanan.

Berdasarkan pemodelan tersebut, diperoleh bahwa kedua tipologi utara dan selatan memiliki beberapa kesamaan karakter ketersediaan infrastruktur perumahan. Pada sub kelompok tersedia dan memenuhi standar, terdapat lima aspek infrastruktur yang memiliki kesamaan, yang meliputi aspek lebar perkerasan jalan, ketersediaan ruang terbuka hijau privat, sinyal telepon sellular, vegetasi pinggir jalan dan drainase di kedua sisi jalan. Pada sub kelompok tersedia namun tidak memenuhi standar (ukuran dan kelengkapan) terdapat aspek pos hansip. Sementara pada sub kelompok tersedia dengan irisan antara memenuhi standar dan tidak, terdapat aspekaspek ketersediaan badan air penerima, lebar damaja, damija, dimensi drainase jalan, ketersediaan wadah sampah priat dan taman RTH perumahan. Pada sub kelompok tidak tersedia padahal semestinya harus ada, terdapat lima aspek yang memiliki kesamaan yang meliputi keberadaan Tempat Pembuangan Sampah Sementara (TPS) dan bahu jalan. Pada sub kelompok tidak tersedia dengan irisan antara seharusnya ada dan belum wajib meliputi aspek sambungan telepon umum, keberadaan sekolah formal Taman Kanak-Kanak (TK) dan keran umum. 
Sementara sub kelompok irisan antara tersedia dan tidak tersedia, terdiri dari aspek-aspek ketersediaan balai pertemuan, jaringan Instalasi Pengolahan Air Limbah (IPAL), parkir umum, bangunan peribadatan dan Jaringan Sistem Penyediaan Air Minum (SPAM). Dari pemetaan aspek infrastruktur tersebut, dapat diketahui bahwa terdapat sembilan aspek infrastruktur yang keberadaannya masih jarang tersedia, baik di perumahan tipologi utara maupun tipologi selatan sebagaimana aspek-aspek yang tertera pada kolom bagian tengah ke arah kiri sebagaimana tertera pada Lampiran 3.

Infrastruktur perumahan tipologi utara menunjukkan karakteristik yang terbagi dalam lima sub-kelompok ketersediaan. Pada sub kelompok tersedia dan memenuhi standar, terdapat aspek lebar dawasja dan Garis Sempadan Bangunan (GSB), adanya air sumur layak konsumsi dan ketersediaan daya listrik. Pada sub kelompok tersedia dengan irisan antara memenuhi standard dan tidak, terdapat aspek sistem angkutan sampah 3 (tiga) kali/minggu, kapasitas gardu listrik dan ketersediaan lampu jalan. Pada sub kelompok tidak tersedia dan belum wajib ada, terdapat aspek balai pengobatan, fasilitas pendidikan Sekolah Dasar (SD), taman bacaan, serta telepon umum dan bis surat. Pada sub kelompok tidak tersedia dengan irisan antara semestinya ada dan belum wajib ada, terdapat aspek posyandu dan keberadaan toko/warung. Sementara pada sub kelompok irisan antara tersedia dan tidak tersedia, meliputi aspek rumah gardu, hidran, jalan pedestrian dan sambungan telepon rumah. Pada tipologi perumahan utara, terdapat sepuluh aspek infrastruktur yang masih jarang ditemui di lingkungan perumahan formal yang dikembangkan oleh pengembang.

Infrastruktur perumahan tipologi selatan menunjukkan karakteristik ketersediaan infrastruktur dengan kecenderungan yang lebih beragam. Pada sub kelompok tersedia dan memenuhi standar, terdapat aspek ketersediaan kapasitas gardu, lampu jalan dan keberadaan toko/warung. Pada sub kelompok tersedia tetapi tidak memenuhi standar, terdapat aspek angkutan sampah 3 (tiga) kali / minggu, rumah gardu, ketersediaan daya listrik. Pada sub kelompok tersedia dengan irisan antara memenuhi standard dan tidak, terdapat aspek lebar daerah pengawasan jalan (dawasja) dan GSB perumahan. Pada kelompok tidak tersedia dengan sub seharusnya ada, terdapat aspek ketersediaan hidran, jalan pedestrian, sambungan telepon umum dan air sumur layak konsumsi. Pada sub kelompok tidak tersedia dengan irisan antara seharusnya ada dan belum wajib, terdapat aspek balai pengobatan, SD, telepon umum dan bis surat. Sementara pada sub kelompok irisan antara tersedia dan tidak, terdapat aspek posyandu, dan taman bacaan. Pada tipologi perumahan selatan, terdapat sembilan aspek infrastruktur yang masih jarang ditemui di lingkungan perumahan formal yang dikembangkan oleh pengembang.

Secara umum terdapat tiga karakter aspek ketersediaan infrastruktur perumahan yang secara signifikan berbeda antara tipologi utara dan selatan. Pada perumahan tipologi utara, terdapat kecenderungan penyediaan yang jauh lebih baik dari perumahan tipologi selatan dalam hal ketersediaan air sumur layak konsumsi dan ketersediaan daya listrik rumah tangga. Kualitas air sumur memang menjadi permasalahan sebagian besar perumahan tipologi selatan karena selain muka air tanahnya yang sudah semakin menurun juga kualitas air sumur yang jauh dari standar layak konsumsi. Dalam hal ini, penghuni wilayah selatan terpaksa mencari solusi untuk memperoleh air bersih kebutuhan rumah tangga sehari-hari dengan membeli eceran. Permasalahan ini berkaitan erat dengan isu ketersediaan cadangan air tanah yang semakin menipis di daerah selatan Bandung akibat tingginya alih fungsi lahan di wilayah utara yang semestinya dimanfaatkan lebih optimal sebagai daerah resapan air tanah. Isu ini semakin mengemuka dengan ketidakmerataan pelayanan jaringan SPAM berikut rendahnya kualitas pelayanannya di lingkungan permukiman.

Perumahan tipologi selatan umumnya menyediakan kapasitas daya listrik 1300 watt. Berdasarkan standar SNI 03-1733-2004, seharusnya daya listrik memenuhi ketersediaan 450 watt/orang. Dengan asumsi setiap keluarga terdiri dari empat penghuni, maka besar daya minimal yang harus tersedia adalah 1800 watt. Perumahan tipologi utara umumnya sudah menggunakan kapasitas daya listrik rata- 
rata diatas 2200 watt. Hal ini bisa saja berhubungan dengan rata-rata tipe perumahan di wilayah selatan yang umumnya memiliki luas yang jauh lebih kecil jika dibandingkan dengan tipe perumahan di wilayah utara. Rumah besar umumnya dilengkapi dengan daya listrik yang besar. Perbedaan aspek ketiga yang menonjol dari tipologi utara dan selatan peri-urban Metropolitan Bandung Raya dapat ditemui pada aspek ketersediaan sarana perdagangan (toko/warung) yang disediakan oleh pengembang. Tipologi selatan menunjukkan ketersediaan yang memenuhi standar melalui ketersediaan ruko pada lingkungan perumahan yang dibangun oleh pengembang dan digunakan sebagai fasilitas komersil oleh penghuninya. Sementara pada perumahan tipologi utara, sama sekali tidak ditemuan konsep ruko. Berdasarkan penuturan penghuni, warga perumahan cenderung menentang keberadaan fasilitas umum komersil untuk berada di dalam lingkungan perumahan utara dikarenakan alasan menjaga privasi.

\subsection{Analisis Aspek Aksesibilitas}

Hasil uji selanjutnya adalah identifikasi aksesibilitas infrastruktur antara tipologi perumahan utara dan selatan Metropolitan Bandung Raya sebagaimana ditunjukkan pada Lampiran 3. Untuk memahami konsep distribusi dan aksesibilitas penggunaan infrastruktur perumahan yang dibangun oleh pengembang, peneliti melakukan wawancara terhadap wakil pengelola dan informan masyarakat yang tinggal di sekitar kawasan perumahan tersebut. Hasil wawancara terkait distribusi dan aksesibilitas penggunaan infrastruktur perumahan bagi masyarakat sekitar selanjutnya dikelompokkan berdasarkan dampak manfaat bagi masyarakat sekitar, apakah berkontribusi positif atau tidak berkontribusi / berkontribusi negatif. Adapun hasil wawancara terhadap para informan tentang konsep distribusi dan aksesibilitas perumahan di keenam lokasi sampel perumahan peri-urban utara dan selatan, dapat dilihat pada Lampiran 3.

Dari pemetaan aksesibilitas dan distribusi pemanfaatan infrastruktur tersebut, selanjutnya dibuatkan model aksesibilitas infrastrktur utara-selatan Metropolitan Bandung Raya dengan tema pengelompokkan yang lebih besar sebagaimana yang tertuang pada Lampiran 4. Tema besar pengelompokkannya dibagi atas 1) kelompok infrastruktur perumahan yang berkontribusi positif dan 2) kelompok infrastruktur perumahan yang tidak berkontribusi positif. Pengertian tidak berkontribusi positif disini dapat berarti tidak memberikan berkontribusi sama sekali kepada lingkungan sekitar atau bahkan berkontribusi negatif. Berdasarkan pemodelan Lampiran 4, terdapat beberapa aspek aksesibilitas infrastruktur yang dimiliki oleh kedua tipologi perumahan sebagaimana terlihat pada baris karakteristik umum. Aspek aksesibilitas infrastruktur perumahan yang dianggap memiliki kontribusi positif oleh masyarakat di luar perumahan, baik pada tipologi utara dan selatan, adalah drainase yang tidak terputus dan tidak adanya jalan buntu. Aspek yang dianggap tidak berkontribusi positif mencakup ketiadaan IPAL untuk lingkungan sekitar, jaringan listrik untuk masyarakat sekitar, jaringan telepon yang dapat diakses masyarakat sekitar, sarana pelayanan umum yang dapat diakses masyarakat sekitar, SPAM yang dapat diakses masyarakat sekitar, TPS dan manajemen angkutan sampah yang dapat diakses masyarakat sekitar, jaringan telepon bagi masyarakat sekitar lingkungan perumahan, jaringan listrik terdistribusi ke lingkungan di sekitar perumahan, sarana pelayanan umum di sekitar lingkungan perumahan, SPAM terdistribusi ke sekitar lingkungan perumahan, TPS di sekitar lingkungan perumahan, pengelolaan limbah di sekitar lingkungan perumahan, pengelolaan limbah di sekitar lingkungan perumahan dan perubahan arah air larian.

Irisan himpunan karakteristik umum aksesibilitas infrastruktur perumahan yang berkontribusi positif maupun yang tidak ditunjukkan pada bagian kolom tengah dari pemodelan Lampiran 4, yang mencakup adanya jaringan jalan yang mengalir, masjid yang dapat diakses masyarakat sekitar, taman RTH dapat diakses masyarakat sekitar, masjid di lingkungan perumahan, pembangunan drainase jalan utama, pelebaran atau pengaspalan jalan, aliran limbah yang tidak langsung dibuang begitu saja ke drainase dan tidak adanya gang sempit. Secara umum, 
karaktersitik umum infrastuktur perumahan peri-urban menunjukkan kecenderungan yang lebih besar terhadap akses yang tidak berkontribusi positif terhadap lingkungan sekitar.

Pada representasi perumahan tipologi utara, karakteristik aksesibilitas infrastruktur perumahan menunjukkan tidak satupun aspek yang kontribusi positif. Aspek yang menonjol justru timbul pada kelompok karakter yang tidak berkontribusi positif, meliputi ketiadaan akses sarana perdagangan, sarana pendidikan dan kesehatan. Sementara irisan kelompok aksesibilitas yang berkontribusi positif dan negatif mencakup aspek tidak adanya drainase perumahan yang melanjutkan dari saluran yang sudah ada (perngembang cenderung membuat akses buangan baru) dan aksesibilitas terhadap taman RTH di sekitar lingkungan perumahan. Pada representasi perumahan tipologi selatan, karakteristik aksesibilitas infrastruktur perumahan yang berkontribusi positif ditunjukkan pada aspek aksesibilitas sarana perdagangan dan ketersediaan taman RTH di sekitar lingkungan perumahan. Sementara aksesibilitas yang dianggap cenderung tidak berkontribusi positif adalah ketiadaan jaringan drainase lanjutan. Irisan antara kelompok aksesbilitas yang berkontribusi positif dan negatif meliputi aksesibilitas pada sarana kesehatan dan sarana pendidikan. Jika melihat dari pemodelan tersebut, maka infrastruktur perumahan pada tipologi selatan memiliki kecenderungan aksesibilitas yang lebih baik bagi masyarakat sekitar dibandingkan dengan perumahan tipologi utara.

Tipologi perumahan peri-urban selatan Metropolitan Bandung Raya menunjukkan keunggulan karakter aksesibilitas pada ketersediaan infrastuktur sarana niaga dan perdagangan yang memenuhi standar, dimana perumahan tipologi utara justru menunjukkan sebaliknya. Dalam hal ini, pengembang perumahan pada lokasi studi peri-urban utara Metropolitan Bandung Raya sejak awal memang tidak mendesain fasilitas perdagangan khusus pada kawasan perumahan, dan penghuni setempat pun umumnya merasa keberatan dengan kehadiran sarana perdagangan di dalam lingkungan perumahan untuk kenyamanan privasi. Sementara bagi perumahan peri-urban selatan Metropolitan Bandung Raya, sarana niaga umumnya telah dirancang oleh pengembang perumahan sejak awal, dengan lokasi strategis di muka kawasan perumahan. Desain ini diapresiasi baik oleh masyarakat setempat maupun masyarakat sekitar, karena pada satu sisi dapat memberikan kontribusi positif dalam aspek aksesibilitas pencapaian sarana niaga bagi masyarakat sekitar dan di sisi lain penghuni perumahan pun tetap terjaga privasinya.

Tidak berkontribusi positif disini tidak selalu bermakna berkontribusi negatif atau mempersulit penghuni, tetapi bisa saja tidak adanya akses bagi masyarakat sekitar untuk memperoleh layanan infrastruktur perumahan, sehingga dianggap tidak berpengaruh apa pun untuk penghuni. Dalam hal ini, masyarakat sekitar menganggap bahwa ketersediaan infrastruktur dan fasilitas perumahan yang dibangun oleh pengembang hanya untuk dipergunakan oleh penghuni internal perumahan. Sehingga sangat wajar jika penggunaan oleh masyarakat luar justru dibatasi. Sehingga, masyarakat sekitar akan sangat mengapresiasi ketika ada perumahan dengan konsep 'terbuka' atau non-gated community yang memungkinkan masyarakat lain dapat mengakses infrastruktur perumahan, khususnya ketersediaan sarana umum, seperti taman, ruang terbuka hijau, masjid serta fasilitas pendidikan dan kesehatan jika tersedia.

Meskipun hasil pemetaan aspek-aspek aksesibilitas penggunaan infrastuktur perumahan oleh masyarakat di luar perumahan mengarah pada kecenderungan tidak berkontribusi positif, namun demikian para informan menyatakan bahwa masuknya perumahan justru membawa dampak positif bagi perkembangan prasarana dasar kawasannya. Mayoritas informan merasakan bahwa keberadaan perumahan telah membantu melakukan pelebaran dan pengaspalan jalan berikut pembangunan drainase di sepanjang jalan-jalan utama menuju ke arah perumahan. Begitu pula dengan hadirnya jaringan utilitas listrik dan telepon, dimana masyarakat merasakan semakin berkembangnya jaringan listrik di wilayahnya setelah masuknya perumahan ke lingkungan sekitar tempat tinggal mereka. Hal-hal yang secara umum 
dianggap berkontribusi negatif terhadap masyarakat, diantaranya adalah kemacetan, kekeringan dan banjir.

Masalah kemacetan timbul akibat meningkatnya jumlah kendaraan yang berasal dari para penghuni baru, masalah kekeringan timbul karena semakin banyaknya penduduk yang melakukan pengeboran sumur untuk memenuhi kebutuhan air bersih, sementara masalah banjir timbul karena semakin berkurangnya resapan dan penataan drainase yang kurang baik. Aspek lain yang mungkin tidak dirasakan secara langsung berkontribusi negatif bagi masyarakat adalah masih banyaknya perumahan yang belum menggunakan IPAL dalam mengelola limbah cair rumah tangga serta mekanisme pembuangan limbah yang langsung dialirkan ke saluran drainase. Dalam hal ini, mekanisme tersebut mencemari lingkungan sekitar, baik dari segi pencemaran udara maupun pencemaran air.

Aksesibilitas infrastruktur perumahan dapat dikatakan sangat berkorelasi dengan konsep penempatan atau posisi perletakan sarana tersebut dalam site lingkungan perumahan. Pada konsep perumahan satu pintu atau gated communities, keberadaan sarana yang berada di dalam lingkungan perumahan secara tidak langsung akan menjadi penghambat akses orang luar untuk dapat memanfaatkannya. Lain halnya jika sarana tersebut berlokasi di area publik atau sisi luar perumahan yang mengindikasikan kemudahan akses bagi penduduk di luar perumahan untuk menjangkau sarana tersebut. Dalam hal ini, keberadaan masjid sebagai sarana ibadah dapat menjadi perkecualian. Meskipun bangunan ibadah tersebut terletak di dalam perumahan, namun masyarkat sekitar tidak merasa sulit untuk ikut memanfaatkannya, khususnya saat menjalankan ibadah Shalat Jumat. Namun demikian, tidak sedikit masyarakat luar yang cenderung 'sungkan' untuk memanfaatkan masjid di lingkungan dalam perumahan. Begitu pula dengan pemanfaatan taman dan RTH di lingkungan dalam perumahan yang dirasakan 'sulit' untuk dijangkau oleh masyarakat sekitar.

Penempatan sarana perumahan yang cukup strategis umunya banyak ditemukan pada penempatan sarana perdagangan (biasanya berupa rumah toko / ruko) yang selalu ditempatkan di area yang bersifat umum dan terbuka. Bagi masyarakat luar, keberadaan sarana pos keamanan yang menjadi ciri khas perumahan sistem tertutup, dapat dipandang sebagai pembatas akses pemanfaatan sarana di lingkungan perumahan.

\section{KESIMPULAN}

Penelitian terhadap tipologi penyediaan infrastruktur perumahan di kawasan peri urban utara-selatan Metropolitan Bandung Raya menunjukkan beberapa kesamaan maupun perbedaan karakter ketersediaan dan aksesibilitas pemanfaatan infrastruktur. Kesamaan karakter ini meliputi ketersediaan yang sesuai standar pada prasarana perkerasan jalan umum, RTH privat, jaringan telepon selular, vegetasi jalan, drainase pinggir jalan serta penyediaan tanki septik perumahan. Tipologi perumahan peri-urban utara Metropolitan Bandung Raya menunjukkan keunggulan pada ketersediaan air minum layak konsumsi dan ketersediaan daya listrik yang sesuai standar. Sementara tipologi perumahan peri-urban selatan Metropolitan Bandung Raya menunjukkan keunggulan ketersediaan infrastuktur sarana niaga dan perdagangan yang memenuhi standar. Kesenjangan ketersediaan infrastruktur peri-urban utaraselatan yang sangat dirasakan terutama dalam hal ketersediaan air minum sebagai salah satu komponen prasarana dasar.

Penelitian kajian mikro pada lokasi studi kasus perumahan yang terletak di Kawasan Periurban Metropolitan Bandung Raya menunjukkan bahwa tidak semua infrastruktur perumahan dibangun memenuhi standar. Dengan ketidakmerataan ketersedian infrastruktur pada akhirnya berdampak pada ketidakseimbangan lingkungan serta ketidakadilan sosial. Dalam hal ini, kelengkapan infrastruktur perumahan yang dibangun seharusnya sudah dilakukan atas izin dan koordinasi dengan Pemerintah Daerah setempat. Hasil kajian lapangan ini, diharapkan dapat menjadi masukan bagi pemerintah daerah sebagai pihak yang berwenang dalam penyelenggaraan perumahan. Pemerintah daerah harus mampu membuat dan menerapkan standarisasi 
penyediaan sarana prasarana perumahan, agar ketersediaan infrastruktur dasar sebagai salah satu barang publik dapat dijangkau secara adil dan merata oleh seluruh lapisan masyarakat.

Dampak negatif yang timbul akibat ketidaktersediaan ataupun ketidakmerataan penyediaan infrastruktur perumahan pada akhirnya akan menjadi beban pemerintah karena seluruh infrastruktur perumahan yang dibangun di lingkungan perumahan pada akhirnya harus diserahterimakan kepada pemerintah. Pemerintah perlu secara konsisten menerapkan standarisasi penyediaan infrastruktur perumahan berikut pengembangan sistem jaringan infrastruktur yang komprehensif, berkesinambungan dan aplikatif untuk dapat diterapkan oleh semua pihak yang terlibat dalam pengembangan permukiman yang berkelanjutan di kawasan Metropolitan Bandung Raya.

\section{UCAPAN TERIMAKASIH}

Penulis mengucapkan terima kasih yang sebesar-besarnya pada Badan Penelitian dan Pengembangan Daerah Provinsi Jawa Barat atas segala dukungan moril dan materil, serta Dr. Eng. Arif Sarwo Wibowo dan Delik Hudalah, Ph.D atas pendampingan selama melaksanakan penelitian ini.

\section{REFERENSI}

Badan Standardisasi Nasional. (2004). Standar Nasional Indonesia No 031733-2004 tentang Tata Cara Perencanaan Lingkungan Perumahan.

Direktorat Perencanaan Penyediaan Perumahan. (2015). Kajian Teknis Penyusunan Masterplan Penyediaan Perumahan Rakyat di Metropolitan Bandung Raya. Jakarta.

Divigalpitiya, P., \& Handayani, K. N. (2010). Measuring the Urban Expansion Process of Yogyakarta City in Indonesia. International Review for Spatial Planning and Sustainable Development, 3(4), 18-19.

Fahmi, F. Z., Hudalah, D., Rahayu, P., \& Woltjer, J. (2014). Extended urbanization in small and medium-sized cities: The case of Cirebon, Indonesia. Habitat International, 42, 1-10. https://doi.org/10.1016/j.habitatint.2013. 10.003

Firman, T. (2009). The continuity and change in mega- urbanization in Indonesia: A survey of Jakarta - Bandung Region ( JBR ) development. Habitat International, 33(4), 327-339.

Guo, Y., Xiao, Y., \& Yuan, Q. (2016). The redevelopment of peri-urban villages in the context of path-dependent land institution change and its impact on Chinese inclusive urbanization: The case of. JCIT, 2.

Hudalah, D., Winarso, H., \& Woltjer, J. (2007). Peri-urbanisation in East Asia : A New Challange for Planning. International Development Planning Review, 29(10), 508.

Hudalah, D., Winarso, H., \& Woltjer, J. (2014). Gentrifying the peri-urban: Land use conflicts and institutional dynamics at the frontier of an Indonesian metropolis. Urban Studies, 2.

Maryati, S., Nisaa, A., \& Humaira, S. (2015). Increasing the Infrastructure Access of Low-Income People in Peri-Urban of Bandung Metropolitan Area. International Journal of Built Environment and Sustainability, 2(3), 219.

Mittal, J., \& Kashyap, A. (2015). Real estate market led land development strategies for regional economic corridors e A tale of two mega projects. Habitat International, 47, 205-217.

Okoro, C. S., Musonda, I., \& Agumba, J. (2016). Identifying Barriers to Urban Residential Infrastructure Development: a Literature Review. In C. Aigbavboa \& W. Thwala (Eds.), International Conference on Infrastructure Development in Africa (p. 468).

Power, E. R., \& Mee, K. J. (2019). Housing: an infrastructure of care. Housing Studies, O(14 May 2019), 2.

Rustiati. (2005). Pengaruh Urban Sprawl Terhadap Struktur Tata Ruang Wilayah Kecamatan Cileunyi Kabupaten Bandung. Institut Teknologi Bandung.

Sheng, Y. K. (2014). Challenges of PeriUrbanization in the Asia-Pacific Region 
Yap Kioe Sheng. International Policy Workshop on Rural-Urban Poverty Linkages, (September), 7. Zhejiang Province, China.

Siahaan, A., Nasution, Z., \& Purwoko, A. (2014). Analisis Pengaruh Pembangunan Perumahan terhadap Pengembangan Wilayah Kecamatan Siantar Marimbun Kota Pematang Siantar. Jurnal Ekonom, 17(3), 103-110.

Tian, L., Ge, B., \& Li, Y. (2016). Impacts of state-led and bottom-up urbanization on land use change in the peri-urban areas of Shanghai : Planned growth or uncontrolled sprawl? JCIT.

UN Habitat. (2015). Habitat III Policy Paper Framework. Retrieved from www.habitat3.org

Vitriana, A. (2018). Infrastructure Provision by Residential Developers in the PeriUrban Neighbourhoods of Metropolitan Bandung Raya. IOP Conference Series: Earth and Environmental Science, 158(1), 4.

Vitriana, Anita. (2017). Kajian Infrastruktur (Perumahan dan Permukiman) di Kawasan Peri-Urban Metropolitan Bandung Raya. Bandung.

Winarso, H. (2000). Residential Land Developer's Behaviour in Jabotabek, Indonesia. University of London.

Winarso, H., Hudalah, D., \& Firman, T. (2015). Peri-urban transformation in the Jakarta metropolitan area. Habitat International, 49(November 2016), 221229. 05.024

Zhang, L., Zhou, T., \& Mao, C. (2019). Does the difference in urban public facility allocation cause spatial inequality in housing prices? Evidence from Chongqing, China. Sustainability (Switzerland), 11(21), 2.

Zhao, P. (2013). Too complex to be managed? New trends in peri-urbanisation and its planning in Beijing. Cities, 30, 68-76. 


\section{LAMPIRAN}

\begin{tabular}{|c|c|c|c|c|c|c|c|c|}
\hline \multirow{2}{*}{\multicolumn{2}{|c|}{ Kriteria }} & Komponen Ketersediaan & \multirow{2}{*}{$\begin{array}{c}\text { GA } \\
\text { U-Kecil }\end{array}$} & \multirow{2}{*}{$\begin{array}{c}\text { GP } \\
\text { U-Menengah }\end{array}$} & \multirow{2}{*}{$\begin{array}{c}\text { PRV } \\
\text { U-Besar }\end{array}$} & \multirow{2}{*}{$\begin{array}{c}\text { SAR } \\
\text { S-Kecil }\end{array}$} & \multirow{2}{*}{$\begin{array}{c}\text { PC } \\
\text { S-Menengah }\end{array}$} & \multirow{2}{*}{$\begin{array}{c}\text { CF } \\
\text { S-Besar }\end{array}$} \\
\hline & & (Teknik Observasi) & & & & & & \\
\hline \multirow{20}{*}{ 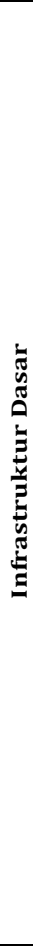 } & \multirow{7}{*}{$\begin{array}{l}\text { Jaringan Jalan (Jalan Lokal } \\
\text { Sekunder dan Jalan Lingungan) }\end{array}$} & $\checkmark$ Perkerasan & $D$ & $D$ & $D$ & $D$ & D & D \\
\hline & & $\checkmark$ Bahu Jalan & B & B & B & B & B & B \\
\hline & & $\checkmark$ Pedestrian & B & B & B & B & B & B \\
\hline & & $\checkmark$ Damaja & C & D & D & C & C & D \\
\hline & & $\checkmark$ Damija & c & D & D & $\mathrm{C}$ & $\mathrm{c}$ & D \\
\hline & & $\checkmark$ Dawasja & D & D & D & D & C & D \\
\hline & & $\checkmark$ GSB Min & D & D & D & C & C & D \\
\hline & \multirow[t]{2}{*}{ Jaringan Drainase } & $\checkmark$ Saluran drainase & D & D & D & D & D & D \\
\hline & & $\checkmark$ Badan air & C & D & D & C & C & D \\
\hline & \multirow[t]{2}{*}{ Jaringan Pembuangan limbah } & $\checkmark$ Tangki Septik & D & D & D & D & D & D \\
\hline & & $\begin{array}{l}\checkmark \text { Jaringan pengolahan air limbah } \\
\text { (IPAL) }\end{array}$ & B & B & B & B & D & B \\
\hline & \multirow[t]{2}{*}{ Jaringan Persampahan } & $\checkmark$ Wadah sampah & D & D & D & D & C & C \\
\hline & & $\begin{array}{l}\checkmark \quad \text { Layanan pengumpulan sampah } \\
\text { (Angkutan sampah \& TPS) }\end{array}$ & C & D & C & C & C & C \\
\hline & \multirow[t]{3}{*}{ Jaringan Air Bersih } & $\checkmark$ Jaringan air bersih & B & C & D & B & B & D \\
\hline & & $\checkmark$ Kran umum & $A$ & B & B & $A$ & B & B \\
\hline & & $\checkmark$ Hidran kebakaran & B & B & B & B & B & B \\
\hline & \multirow[t]{2}{*}{ Jaringan Listrik } & $\checkmark$ Kebutuhan daya listrik, & D & D & D & C & C & C \\
\hline & & $\checkmark$ Kebutuhan jaringan listrik & B & D & D & D & D & D \\
\hline & \multirow[t]{2}{*}{ Jaringan Telepon } & $\checkmark$ Jaringan telepon kabel & $A$ & B & D & A & B & B \\
\hline & & $\checkmark$ Jaringan telepon selular & D & D & D & D & D & D \\
\hline \multirow{14}{*}{ 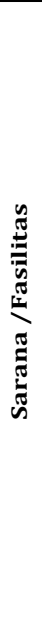 } & Sarana Peribadatan & $\begin{array}{l}\checkmark \text { Bangunan peribadatan (mushola / } \\
\text { masjid) }\end{array}$ & $A$ & $\mathrm{D}$ & $\mathrm{D}$ & $A$ & $\mathrm{D}$ & D \\
\hline & \multirow{2}{*}{$\begin{array}{l}\text { Sarana Ruang Terbuka, Taman } \\
\text { dan Lapangan }\end{array}$} & $\checkmark$ RTH Privat & D & D & D & D & D & D \\
\hline & & $\checkmark$ Taman RTH & D & D & D & C & D & D \\
\hline & Sarana Pemerintahan dan & $\checkmark$ Balai pertemuan & A & C & D & A & C & D \\
\hline & \multirow[t]{4}{*}{ Pelayanan Umum } & $\checkmark$ Pos hansip & C & C & C & C & C & C \\
\hline & & $\checkmark$ Gardu listrik & A & C & C & C & C & C \\
\hline & & $\checkmark$ Telepon umum dan bis surat & A & A & A & A & A & B \\
\hline & & $\checkmark$ Parkir umum & $A$ & B & D & A & B & D \\
\hline & \multirow{3}{*}{$\begin{array}{l}\text { Sarana Pendidikan dan } \\
\text { Pembelajaran }\end{array}$} & $\checkmark$ Taman kanak-kanak & A & A & A & A & B & B \\
\hline & & $\checkmark$ Sekolah Dasar & A & A & A & A & B & B \\
\hline & & $\checkmark$ Taman Bacaan & A & A & A & A & A & D \\
\hline & \multirow[t]{2}{*}{ Sarana Kesehatan } & $\checkmark$ Posyandu & A & A & B & A & B & D \\
\hline & & $\checkmark$ Balai Pengobatan warga & $A$ & $A$ & A & A & $A$ & B \\
\hline & Sarana Perdagangan dan Niaga & $\checkmark$ Toko / Warung & A & B & B & D & D & D \\
\hline
\end{tabular}

Lampiran 1. Identifikasi Ketersediaan Infrastruktur Perumahan dan Permukiman pada Keenam Lokasi Studi Kasus Perumahan di Kawasan Peri-Urban Metropolitan Bandung Raya

Keterangan: Sumber: Hasil Survey dan Observasi (2017)

U : Utara (Desa Ciwaruga)

S : Selatan (Desa Cipagalo)

A : Tidak tersedia, namun belum wajib ada

B : Tidak tersedia, seharusnya ada

C : Tersedia, namun tidak memenuhi standar

D : Tersedia, memenuhi standar 


\begin{tabular}{|c|c|c|c|c|c|c|}
\hline \multicolumn{3}{|c|}{ Tidak tersedia } & & & \multicolumn{2}{|l|}{ Tersedia } \\
\hline \multicolumn{2}{|c|}{ Belum wajib ada } & Seharusnya ada & & \multicolumn{2}{|c|}{ Tidak memenuhi standar } & emenuhi standar \\
\hline \multicolumn{7}{|c|}{ TIPOLOGI UTARA } \\
\hline \multirow[t]{3}{*}{$\begin{array}{l}\text { - Balai } \\
\text { Pengobatan } \\
\text {-Sekolah Dasar } \\
\text { - Taman Bacaan } \\
\text { - Telepon Umum } \\
\text { dan Bis Surat }\end{array}$} & $\begin{array}{l}\text { - Posyandu } \\
\text {-Toko / } \\
\text { Warung }\end{array}$ & & $\begin{array}{l}\text { - Bangunan } \\
\text { peribadatan } \\
\text { - Rumah gardu } \\
\text { - Hidran } \\
\text { kebakaran } \\
\text { - Pedestrian jln } \\
\text { - Sambungan } \\
\text { tele bon ruma }\end{array}$ & & $\begin{array}{l}\text {-Angkutan } \\
\text { sampah } 3 \mathrm{x} \\
\text { seminggu } \\
\text { - Kapasitas } \\
\text { gardu listrik } \\
\text { - Lampu jalan }\end{array}$ & $\begin{array}{l}\text { - Dawasja } \\
\text {-GSB } \\
\text { - Air sumur } \\
\text { layak } \\
\text { konsumsi } \\
\text {-Daya listrik RT }\end{array}$ \\
\hline & $\begin{array}{l}\text {-Sambungan } \\
\text { telepon } \\
\text { umum } \\
\text {-Taman } \\
\text { kanak- kanak } \\
\text { - Kran umum }\end{array}$ & $\begin{array}{l}\text {-TPS } \\
\text { - Bahu Jalan }\end{array}$ & $\begin{array}{l}\text { - Balai } \\
\text { pertemuan } \\
\text { - Jaringan IPAL } \\
\text { - Parkir umum } \\
\text { - Jaringan } \\
\text { SPAM }\end{array}$ & - Pos hansip & $\begin{array}{l}\text { - Badan air } \\
\text { penerima } \\
\text {-Damaja } \\
\text { - Damija } \\
\text { - Drainase jalan } \\
\text { - Wadah } \\
\text { sampah } \\
\text {-Taman RTH }\end{array}$ & $\begin{array}{l}\text { - Perkerasan } \\
\text { jalan } \\
\text { - RTH privat } \\
\text { - Sinyal HP } \\
\text { - Vegetasi jalan } \\
\text { - Drainase kanan } \\
\text { kiri jalan } \\
\text { - Tangki Se ptik }\end{array}$ \\
\hline & $\begin{array}{l}\text { - Balai } \\
\text { pengobatan } \\
\text { warga } \\
\text {-Sekolah } \\
\text { dasar } \\
\text {-Telepon } \\
\text { umum dan } \\
\text { bis surat }\end{array}$ & $\begin{array}{l}\text { - Hidran } \\
\text { kebakaran } \\
\text { - Pedestrian } \\
\text { jalan } \\
\text { - Sambungan } \\
\text { telepon rumah } \\
\text { - Air sumur } \\
\text { layak konsumsi }\end{array}$ & $\begin{array}{l}\text { - Posyandu } \\
\text { - Taman } \\
\text { bacaan }\end{array}$ & $\begin{array}{l}\text { - Angkutan } \\
\text { sampah } 3 x \\
\text { sem inggu } \\
\text { - Rumah gardu } \\
\text { - Daya listrik RT }\end{array}$ & $\begin{array}{l}\text { - Bangunan } \\
\text { peribadatan } \\
\text {-Dawasja } \\
\text {-GSB }\end{array}$ & $\begin{array}{l}\text { - Kapasitas } \\
\text { gardu listrik } \\
\text { - Lampu jalan } \\
\text { - Toko/warung }\end{array}$ \\
\hline \multicolumn{7}{|c|}{ TIPOLOGI SELATAN } \\
\hline Belum wajib ac & Tidak ter & Seharusnya ada & & k memenuhi star & Idar & lemenuhi standar \\
\hline
\end{tabular}

Lampiran 2. Karakteristik ketersediaan Infrastruktur Perumahan dan Permukiman di Kawasan Peri-Urban Metropolitan Bandung Raya Berdasarkan Tipologi Utara - Selatan Sumber: Hasil Pengolahan Data (2017)

Keterangan:

Karakteristik Umum 


\begin{tabular}{|c|c|c|c|c|c|c|c|c|}
\hline \multirow{2}{*}{\multicolumn{2}{|c|}{ Kriteria }} & Komponen Aksesibilitas & GA & GP & PRV & SAR & PC & CF \\
\hline & & (Teknik Wawancara) & U-Kecil & U-Menengah & U-Besar & S-Kecil & S-Menengah & S-Besar \\
\hline \multirow{14}{*}{ 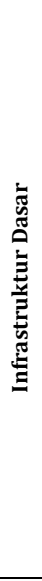 } & \multirow{4}{*}{$\begin{array}{l}\text { Jaringan Jalan (Jalan Lokal } \\
\text { Sekunder dan Jalan } \\
\text { Lingungan) }\end{array}$} & $\checkmark$ Pelebaran/pembukaan jalan utama & $\mathrm{N}$ & $P$ & $P$ & $\mathrm{~N}$ & $P$ & $P$ \\
\hline & & $\checkmark$ Tidak ada jalan terputus & $\mathrm{P}$ & $P$ & $P$ & $\mathrm{P}$ & $P$ & $P$ \\
\hline & & $\begin{array}{l}\checkmark \text { Terdapat jalan desa berdampingan dengan } \\
\text { jalan perumahan (pembatasan penggunaan }\end{array}$ & $\mathrm{N}$ & $\mathrm{P}$ & $\mathrm{N}$ & $\mathrm{P}$ & $\mathrm{N}$ & $\mathrm{N}$ \\
\hline & & $\begin{array}{l}\checkmark \text { Akses terkunci (1 pintu) dan terbuka (2 } \\
\text { pintu) }\end{array}$ & $\mathrm{N}$ & $\mathrm{P}$ & $\mathrm{N}$ & $\mathrm{N}$ & $\mathrm{N}$ & $P$ \\
\hline & \multirow[t]{2}{*}{ Jaringan Drainase } & $\checkmark$ Pembangunan drainase jalan utama & $\mathrm{N}$ & $P$ & $P$ & $\mathrm{~N}$ & $P$ & $P$ \\
\hline & & 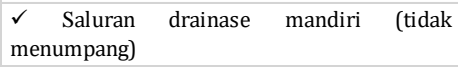 & $\mathrm{N}$ & $\mathrm{P}$ & $\mathrm{P}$ & $\mathrm{P}$ & $P$ & $P$ \\
\hline & \multirow[t]{2}{*}{ Jaringan Pembuangan limbah } & $\checkmark$ IPAL yang dapat digunakan bersama & $\mathrm{N}$ & $\mathrm{N}$ & $\mathrm{N}$ & $\mathrm{N}$ & $\mathrm{N}$ & $\mathrm{N}$ \\
\hline & & $\checkmark$ Pembuangan air limbah yang diolah & $\mathrm{N}$ & $\mathrm{N}$ & $P$ & $\mathrm{~N}$ & $P$ & $\mathrm{~N}$ \\
\hline & \multirow[t]{2}{*}{ Jaringan Persampahan } & $\checkmark$ TPS yang dapat digunakan bersama & $\mathrm{N}$ & $\mathrm{N}$ & $\mathrm{N}$ & $\mathrm{N}$ & $\mathrm{N}$ & $\mathrm{N}$ \\
\hline & & $\checkmark$ Sistem pengangkutan sampah bersama & $\mathrm{N}$ & $\mathrm{N}$ & $\mathrm{N}$ & $\mathrm{N}$ & $\mathrm{N}$ & $\mathrm{N}$ \\
\hline & Jaringan Air Bersih & $\checkmark$ Jaringan air bersih bersama & $\mathrm{N}$ & $\mathrm{N}$ & $\mathrm{N}$ & $\mathrm{N}$ & $\mathrm{N}$ & $\mathrm{N}$ \\
\hline & \multirow[t]{2}{*}{ Jaringan Listrik } & \multirow{2}{*}{$\begin{array}{l}\checkmark \text { Lampu, gardu, tiang listrik dimanfaatkan } \\
\text { bersama }\end{array}$} & $\mathrm{N}$ & $\mathrm{N}$ & $\mathrm{N}$ & $\mathrm{N}$ & $\mathrm{N}$ & $\mathrm{N}$ \\
\hline & & & & & & $\mathrm{N}$ & $\mathrm{N}$ & $\mathrm{N}$ \\
\hline & Jaringan Telepon & $\checkmark$ Jaringan telepon bersama & $\mathrm{N}$ & $\mathrm{N}$ & $\mathrm{N}$ & $\mathrm{N}$ & $\mathrm{N}$ & $\mathrm{N}$ \\
\hline \multirow{12}{*}{ 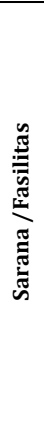 } & \multirow[t]{2}{*}{ Sarana Peribadatan } & $\checkmark$ Aksesibilitas (kemudahan akses capaian) & $\mathrm{N}$ & $\mathrm{P}$ & $\mathrm{P}$ & $\mathrm{N}$ & $\mathrm{P}$ & $\mathrm{P}$ \\
\hline & & $\checkmark$ Perletakan spasial yang merata (distribusi) & $\mathrm{N}$ & $P$ & $P$ & $\mathrm{~N}$ & $P$ & $\mathrm{P}$ \\
\hline & \multirow{2}{*}{$\begin{array}{l}\text { Sarana Ruang Terbuka, } \\
\text { Taman dan Lapangan }\end{array}$} & $\checkmark$ Aksesibilitas (kemudahan akses capaian) & $\mathrm{N}$ & $P$ & $\mathrm{~N}$ & $\mathrm{~N}$ & $\mathrm{~N}$ & $P$ \\
\hline & & $\checkmark$ Perletakan spasial yang merata (distribusi) & $\mathrm{P}$ & $\mathrm{P}$ & $\mathrm{P}$ & $\mathrm{P}$ & $\mathrm{P}$ & $\mathrm{P}$ \\
\hline & \multirow{2}{*}{$\begin{array}{l}\text { Sarana Pemerintahan dan } \\
\text { Pelayanan Umum }\end{array}$} & $\checkmark$ Aksesibilitas (kemudahan akses capaian) & $\mathrm{N}$ & $\mathrm{N}$ & $\mathrm{N}$ & $\mathrm{N}$ & $\mathrm{N}$ & $\mathrm{N}$ \\
\hline & & $\checkmark$ Perletakan spasial yang merata (distribusi) & $\mathrm{N}$ & $\mathrm{N}$ & $\mathrm{N}$ & $\mathrm{N}$ & $\mathrm{N}$ & $\mathrm{N}$ \\
\hline & \multirow{2}{*}{$\begin{array}{l}\text { Sarana Pendidikan dan } \\
\text { Pembelajaran }\end{array}$} & $\checkmark$ Aksesibilitas (kemudahan akses capaian) & $\mathrm{N}$ & $\mathrm{N}$ & $\mathrm{N}$ & $\mathrm{N}$ & $\mathrm{N}$ & $\mathrm{P}$ \\
\hline & & $\checkmark$ Perletakan spasial yang merata (distribusi) & $\mathrm{N}$ & $\mathrm{N}$ & $\mathrm{N}$ & $\mathrm{N}$ & $\mathrm{N}$ & $P$ \\
\hline & \multirow[t]{2}{*}{ Sarana Kesehatan } & $\checkmark$ Aksesibilitas (kemudahan akses capaian) & $\mathrm{N}$ & $\mathrm{N}$ & $\mathrm{N}$ & $\mathrm{N}$ & $\mathrm{N}$ & $\mathrm{P}$ \\
\hline & & $\checkmark$ Perletakan spasial yang merata (distribusi) & $\mathrm{N}$ & $\mathrm{N}$ & $\mathrm{N}$ & $\mathrm{N}$ & $\mathrm{N}$ & $\mathrm{P}$ \\
\hline & \multirow{2}{*}{$\begin{array}{l}\text { Sarana Perdagangan dan } \\
\text { Niaga }\end{array}$} & $\checkmark$ Aksesibilitas (kemudahan akses capaian) & $\mathrm{N}$ & $\mathrm{N}$ & $\mathrm{N}$ & $\mathrm{P}$ & $\mathrm{P}$ & $\mathrm{P}$ \\
\hline & & $\checkmark$ Perletakan spasial yang merata (distribusi) & $\mathrm{N}$ & $\mathrm{N}$ & $\mathrm{N}$ & $P$ & $P$ & $P$ \\
\hline
\end{tabular}

Lampiran 3. Identifikasi Aksesibilitas dan Distribusi Infrastruktur Perumahan dan Permukiman pada Keenam Lokasi Studi Kasus Perumahan di Kawasan Peri-Urban Metropolitan Bandung Raya

Keterangan:

$\mathrm{U}:$ Utara (Desa Ciwaruga)

S : Selatan (Desa Cipagalo)
Sumber: Hasil Wawancara (2017)

$\mathrm{P}$ : Berkontribusi positif pada lingkungan dan masyarakat sekitar

$\mathrm{N}$ : Tidak berontribusi / berkontribusi negatif pada lingkungan dan masyarakat sekitar
Tidak Berkontribusi / Berkontribusi Negatif terhadap Lingkungan Sekitar

Akses sarana perdagangan
Akses sarana kesehatan
Akses sarana pendidikan
Distribusi sarana perdagangan
Distribusi sarana kesehatan
Distribusi sarana pendidikan
Aksesibilitas IPAL
Aksesibilitas jaringan Listrik
Aksesibilitas.jaringan telepon
Aksesibilits sarana pelayanan umum
Aksesibilitas SPAM
Aksesibilitas TPS/sistem angkut sampah
Distribusi jaringan telepon
Distribusi jaringan listrik
Distribusi sarana pelayanan umum
Distribusi SPAM
Distribusi TPS
Distribusi pengelolaan limbah
Distribusi perubahan arah air larian

Aksesibilitas jaringan drainase lanjutan

Distribusi masjid

utama

baru

drainase
Berkontribusi Positif terhadap Lingkungan Sekitar

Aksesibilitas jaringan drainase lanjutan Distribusi Taman / RTH

Aksesibilitas jaringan jalan mengalir Aksesibilitas masjid

Aksesibilitas taman RTH

Distribusi pembangunan drainase jalan

Distribusi pelebaran/pembukaan jalan

Distribusi aliran limbah tidak langsung ke

Distribusi tidak ada gang sempit

Aksesbilitas sarana kesehatan
Aksesibilitas sarana pendidikan
Distribusi sarana kesehatan
Distribusi sarana pendidikan

Distribusi drainase tdk terputus Distribusi tidak ada jalan buntu

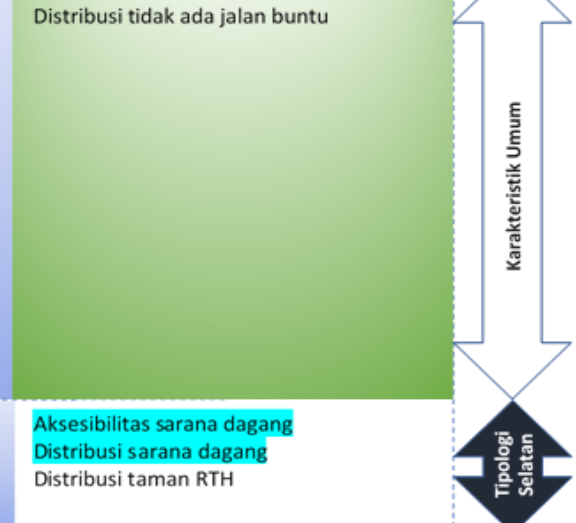

Distribusi taman RTH

Lampiran 4. Karakteristik Aksesibilitas dan Distribusi Infrastruktur Perumahan dan Permukiman di Kawasan Peri-Urban Metropolitan Bandung Raya Berdasarkan Tipologi Utara - Selatan Sumber: Hasil Pengolahan Data (2017) 